\title{
Legislative and Other Selected Challenges Affecting Financial Inclusion for the Poor and Low Income Earners in South Africa
}

\author{
Howard Chitimira* \\ North-West University, South Africa \\ tafarachitimira@gmail.com \\ Menelisi Ncube** \\ North-West University, South Africa \\ ncubemenelisi04@gmail.com
}

\begin{abstract}
This article discusses the challenges affecting the achievement of financial inclusion for the poor and low-income earners in South Africa. The concept of financial inclusion could be defined as the provision of affordable financial products and services to all members of the society by the government and/or other relevant role-players such as financial services providers. This article identifies unemployment, poverty, financial illiteracy, over-indebtedness, high bank fees, mistrust of the banking system, lack of relevant national identity documentation and poor legislative framework for financial inclusion as some of the challenges affecting the full attainment of financial inclusion for the poor and low-income earners in South Africa. Given these flaws, the article highlights the need for the government, financial institutions and other relevant stakeholders to adopt legislative and other measures as an antidote to financial exclusion and poverty challenges affecting the poor and low-income earners in South Africa.
\end{abstract}

\section{Keywords}

Financial inclusion, low-income earners, poverty, financial exclusion, financial legislation

* LLB (cum laude), LLM (University of Fort Hare), LLD (Nelson Mandela Metropolitan University). Professor of securities and financial markets law, Faculty of Law, NorthWest University, South Africa.

** LLB, LLM (North-West University). LLD candidate, Faculty of Law, North-West University, South Africa. This article is influenced in part by M Ncube "A statutory regulatory analysis of financial inclusion for the poor and low-income earners in South Africa" (LLM dissertation, North-West University, 2018) at 62-80. In this regard, the author wishes to acknowledge the expert input of Prof H Chitimira.

This article was also supported in part by the National Research Foundation of South Africa (NRF), grant no 112115. In this regard, the authors wish to thank the NRF for its valuable support. 


\section{INTRODUCTION}

The concept of financial inclusion could be defined as the provision of affordable financial products and services to all members of society by the government and/or other relevant role-players, such as financial services providers. ${ }^{1}$ Financial inclusion enables all persons to have legal ownership of their financial products and/or bank accounts at any lawfully registered financial institution in their country after complying with all relevant requirements. Financial inclusion may further empower all financial consumers to borrow money formally from banks and other registered financial service providers in a bid to alleviate their poverty. Financial inclusion is vitally important to all persons, especially the poor and low-income earners in South Africa. ${ }^{2}$ Accordingly, the South African government should adopt more sustainable measures to empower the poor and low-income earners financially and economically, so as to reverse the negative effects of apartheid upon all its citizens. This approach could promote financial inclusion for the poor and low-income earners and close the gap between the poor and the rich in South Africa.

On the contrary, financial exclusion could, inter alia, refer to the inability of the affected persons to formally access and use financial services and financial products at an affordable cost in any country. Thus, financial exclusion could mean the removal, exclusion, disqualification or prohibition of certain persons from accessing financial products and services such as loans, credit, bank accounts and insurance cover from relevant financial services providers. ${ }^{3}$ Our emphasis is that financial exclusion is mostly detrimental to the socioeconomic wellbeing of the poor and low-income earners in South Africa and many other developing countries, such as Zimbabwe. Poverty aggravated financial exclusion is common in South Africa; it affects the poor and lowincome earners that cannot afford formal and informal high banking costs, related financial services costs and costs for financial products. Thus, notwithstanding the fact that financial inclusion has relatively improved in South Africa, with a total of 32.5 million adults of the total population having access to the formal banking sector between 2008 and $2015,{ }^{4}$ a significant number of

1 M Mohieldin, Z Iqbal, A Rostom and X Fu "The role of Islamic finance in enhancing financial inclusion in Organization of Islamic Cooperation (OIC) countries" (2011, World Bank Islamic Economics and Finance Working Group policy research working paper 5920) at 3.

2 EL Nanziri "Financial inclusion and welfare in South Africa: Is there a gender gap?" (2016) 18/2 Journal of African Development 109. It must be noted that this article provides no comparative analysis on the regulation and promotion of financial inclusion in other jurisdictions, owing to space limitations and the fact that the article is specifically focused on the South African position.

3 MH Warsame "The role of Islamic finance in tackling financial exclusion in the UK" (doctoral thesis, Durham University, 2009) at 16-46.

4 T Arun and R Kamath "Financial inclusion: Policies and practices" (2015) 27 IIMB Management Review 267 at 281; "Finscope South Africa 2015" (Finmark Trust), available 
the poor and low-income earners are still excluded from accessing most basic financial services and financial products. About 30 million South Africans are still poor and some of them struggle to access financial services and financial products due to, inter alia, lack of the required documentation to open a bank account, lack of trust in the banks, high bank fees and financial illiteracy. ${ }^{5}$ Some South African adults have bank accounts but some of these persons withdraw their income immediately instead of saving for future financial obligations. ${ }^{6}$ This shows that some people in South Africa are not actively using their accounts to achieve better financial goals and/or taking advantage of financial services at their disposal to save and invest through their own bank accounts. ${ }^{7}$ Moreover, most poor people in South Africa rely on government social grants and they cannot afford, nor do they qualify for, bank accounts. ${ }^{8}$

In light of the above, it must be noted that there is voluntary and involuntary financial exclusion. ${ }^{9}$ The poor and low-income earners may sometimes voluntarily exclude themselves from accessing certain financial products and services owing to their mistrust of the banking sector and their cultural beliefs. ${ }^{10}$ On the other hand, some poor and low-income earners are involuntarily excluded from accessing basic financial services and financial products due to their low income that is insufficient for them to open and maintain bank accounts. The poor and low-income earners are also discouraged from accessing such services and products due to other stringent requirements by

contd

at: <http://www.finmark.org.za/wp-content/uploads/2016/03/Broch_FinScopeSA2015_ Consumersurvey_FNL.pdf> (last accessed 17 April 2020).

5 F Allen, L Klapper, A Demirgüç-Kunt and MSM Peria "The foundations of financial inclusion: Understanding ownership and use of formal accounts" (2016) 27 Journal of Financial Intermediation 1 at 18-27; R Abrahams "Financial inclusion in South Africa: A review of the literature" (2017) Southern African Accounting Association 632 at 639-40; L Louis and F Chartier "Financial inclusion in South Africa: An integrated framework for financial inclusion of vulnerable communities in South Africa's regulatory system reform" (2017) 1/1 Journal of Comparative Urban Law and Policy 170 at 182-96; K Kessler et al "Improving financial inclusion in South Africa" (2017, Boston Consulting Group) at 3; EL Nanziri and M Leibbrandt "Measuring and profiling financial literacy in South Africa” (2018) 21/1 South African Journal of Economic and Management Sciences 1.

$6 \quad$ Kessler et al, id at 4-5; Abrahams, ibid.

$7 \quad$ Kessler et al, ibid.

8 Ibid.

9 Abrahams "Financial inclusion in South Africa", above at note 5 at 639-40; Arun and Kamath "Financial inclusion", above at note 4 at 281-87; D Gupta "Key barriers faced in implementing financial inclusion" (2015) 3/1 International Journal of Engineering Technology, Management and Applied Sciences 171; C Gortsos "Financial inclusion: An overview of its various dimensions and the initiatives to enhance its current level” (2016) SSRN Electronic Journal 1 at 10.

10 A Demirgüç-Kunt, L Klapper, D Singer and P Van Oudheusden "The global findex database 2014: Measuring financial inclusion around the world" (2015, policy research working paper 7255); Abrahams "Financial inclusion in South Africa", above at note 5 at 635 and $639-40$. 
the banks and related financial institutions. ${ }^{11}$ Additionally, high bank charges and a lack of financial literacy also cause financial exclusion of the poor and low-income earners in South Africa. ${ }^{12}$

The authors argue that financial exclusion negatively affects the promotion of socio-economic development and the reduction of poverty for the poor and low-income earners who cannot afford to save money for other important socio-economic services like those related to their health and education. Financial exclusion also prevents the poor and low-income earners from accessing most basic financial services and financial products in South Africa. ${ }^{13}$ It is because of this and related flaws that financial inclusion should be carefully and valuably promoted to increase the growth of South Africa's gross domestic product (GDP). Proper implementation of financial inclusion laws and regulations could also attract foreign direct investment (FDI) and create more business opportunities and jobs for the poor and low-income earners in South Africa. ${ }^{14}$ For instance, the provision of affordable financial services and financial products by banks and related financial institutions could help the poor and lowincome earners to obtain high quality financial services and financial products that may promote economic stability, public investor confidence and market integrity in South Africa. ${ }^{15}$ Accordingly, financial inclusion could enable South Africa to fight poverty and empower the poor and low-income earners to access basic financial services, financial products and credit rights fairly. ${ }^{16}$

11 V Matsebula and D Yu "Financial inclusion in South Africa: A NIDS data analysis of household access and the usage of financial services and products" (paper presented at the Biennial Conference of the Economic Society of South Africa, 2017). See also related discussion by CY Park and RV Mercado "Does financial inclusion reduce poverty and income inequality in developing Asia?” (2015, Asian Development Bank economics working paper series no 426).

12 G Pearson, PN Stoop and M Kelly-Louw "Balancing responsibilities: Financial literacy" (2017) 20/1 Potchefstroom Electronic Law Journal; Abrahams "Financial inclusion in South Africa", above at note 5 at 635 and 639-40.

13 M Sarma and J Pais "Financial inclusion and development" (2011) 23/5 Journal of International Development 613; CK Oji "Promoting financial inclusion for inclusive growth in Africa" (2015, South African Institute of International Affairs Economic Diplomacy Programme occasional paper 210); M Chibba "Financial inclusion, poverty reduction and the Millennium Development Goals" (2009) 21/2 European Journal of Development Research 213.

14 A Ikdal "6 Challenges to financial inclusion in South Africa" (2017, World Economic Forum) at 5; A Demirgüç-Kunt, L Klapper and D Singer "Financial inclusion and inclusive growth: A review of recent empirical evidence" (2017, World Bank Policy Research working paper WPS 8040); A Demirgüç-Kunt, L Klapper and D Singer "What do we know about the link between financial inclusion and inclusive growth?” (2017) World Bank Blogs, available at: <https://blogs.worldbank.org/allaboutfinance/what-do-we-know-abo ut-link-between-financial-inclusion-and-inclusive-growth> (last accessed 17 April 2020).

15 R Ramakrishnan "BFSI: Best practices in financial inclusion" (paper presented at the India Decide, 22nd Skoch summit 2010 conference, 17-19 March 2010, New Delhi, India) at 5-12.

16 D Jin "The inclusive finance have [sic] effects on alleviating poverty" (2017) 5/3 Open Journal of Social Sciences 233. 
In light of the above, this article discusses selected contemporary challenges hindering the full achievement of financial inclusion for the poor and lowincome earners in South Africa. The article identifies unemployment, poverty, financial illiteracy, over-indebtedness, high bank fees, mistrust of the banking system, a lack of relevant national identity documentation and a poor legislative framework for financial inclusion as some of the challenges affecting the full attainment of financial inclusion for the poor and low-income earners in South Africa. These aforesaid challenges have to date delayed South Africa in achieving its target of reaching 90 per cent financial inclusion by 2030, as set out in the National Development Plan (NDP). ${ }^{17}$ Given these flaws, it is submitted that the government and other relevant stakeholders should adopt robust measures and policies to alleviate poverty and curb financial exclusion to enable the poor and low-income earners to have formal bank accounts and shun illegal high cost credit lenders in South Africa. This article highlights the need for the government, financial institutions and other relevant stakeholders to adopt more appropriate measures to enhance financial inclusion for the poor and low-income earners in South Africa as a legislative antidote to financial exclusion and poverty challenges. It is submitted that the government and financial institutions should promote social justice, equity and sustainable transformation for all persons, especially the poor and low-income earners, to enable them to access convenient, affordable and good financial services and financial products in South Africa. ${ }^{18}$

\section{CHALLENGES TO FINANCIAL INCLUSION IN SOUTH AFRICA}

\section{Unemployment and poverty}

Unemployment and poverty are huge impediments to the full realization and attainment of financial inclusion in South Africa. Most poor, unemployed and low-income earners can barely afford bank accounts and their related transaction costs. ${ }^{19}$ According to the Statistics South Africa 2017 report, poverty levels were very high and about 30.4 million South Africans were living in poverty and they were unable to sustain their bank accounts. ${ }^{20}$ These poverty trends were mainly influenced by poor economic growth, high unemployment levels, high prices for basic commodities, low investment rates and too

17 K Mathe "Future for South Africa's national development plan (NDP) 2030" (16 August 2017, The Banking Association South Africa), available at: <https:/www.banking.org.za/ news-media/association-news/the-ndp-at-five-time-for-active-citizens-to-drive-development> (last accessed 17 April 2020).

18 S Kelly Financial Inclusion 2020 Progress Report (2015, Center for Financial Inclusion), available at: <https://www.centerforfinancialinclusion.org/program_teams/financial-inclus ion-2020-progress-report/> (last accessed 17 April 2020).

19 M Chibba and JM Luiz "Poverty, inequality and unemployment in South Africa: Context, issues and the way forward" (2011) 30/3 A Journal of Applied Economics and Policy 307.

20 Poverty Trends in South Africa: An Examination of Absolute Poverty Between 2006 and 2015 (2017, Statistics South Africa) at 14. 
much reliance on high interest credit loans on the part of many South African individuals. ${ }^{21}$ Consequently, about 30.4 million South African adults could not afford bank accounts and remained excluded from accessing basic financial services and financial products. ${ }^{22}$ Moreover, the poor and low-income earners who are informally employed carry out most of their day-to-day dealings in cash, since they do not qualify to utilize formal banking institutions for the purposes of saving and/or budgeting for future financial obligations. ${ }^{23}$ Although the use of cash does not amount to financial exclusion per se, the poor and low-income earners, who are mostly illiterate and so unable to transact through internet banking or other digital channels, are the ones who transact in cash without opening bank accounts or saving for the future. ${ }^{24}$

The NDP stipulates that South Africa should strive to eliminate poverty through financial inclusion, especially of the poor and low-income earners. ${ }^{25}$ Nonetheless, the South African government has so far failed to create more jobs for the poor and low-income earners, who have largely remained excluded from accessing and utilizing most basic financial services and financial products. ${ }^{26}$ This clearly shows that unemployment and poverty are still huge impediments to the full attainment of financial inclusion for the poor and low-income earners in South Africa. Nonetheless, there is no legislation that expressly addresses unemployment and poverty challenges to financial inclusion in South Africa.

\section{Financial illiteracy}

Financial literacy refers, inter alia, to the ability of an individual to make well informed judgments and decisions regarding the management of their finances for both short and long term financial goals, taking into consideration any change that could occur in economic events and/or related aspects. $^{27}$ This suggests that individuals must have some basic education, skills, understanding and knowledge of various financial services and products to enable them to make correct decisions regarding their personal finance, credit borrowing and investments. Financial illiteracy occurs when

21 Id at 16; P Kostov, T Arun and S Annim "Access to financial services: The case of the 'Mzansi' account in South Africa” (2015) 5/1 Review of Development Finance 34.

22 See J Goldberg "Products and policies to promote saving in developing countries" (2014) IZA World of Labor 1.

23 Kessler et al "Improving financial inclusion", above at note 5.

24 PK Ozili "Impact of digital finance on financial inclusion and stability" (2018) 18/4 Borsa Istanbul Review 329.

25 Poverty Trends, above at note 20 at 28; National Planning Commission "National development plan 2030: Our future - make it work" (2012, Government of South Africa) at 150-51.

26 Poverty Trends, id at 14-123; Kessler et al "Improving financial inclusion", above at note 5.

27 A Zait and PE Bertea "Financial literacy: Conceptual definition and proposed approach for a measurement instrument" (2014) 4/3 Journal of Accounting and Management 37; A Dwiastanti "Financial literacy as the foundation for individual financial behavior" (2015) 6/33 Journal of Education and Practice 99. 
financial consumers do not have the basic education, skills, understanding and knowledge of the available financial services and products to enable them to make informed decisions regarding their personal finance, credit borrowing and investments in the future. ${ }^{28}$ Financial literacy has various components such as financial education, financial knowledge, financial competence and financial responsibility which are all crucial for the achievement of financial inclusion. ${ }^{29}$ These components relate to financial consumers' personal understanding of financial concepts, financial institutions and financial regulations, as well as the empowerment of such consumers with the knowledge, skills and confidence to understand, manage and make well-informed financial decisions. ${ }^{30}$ Consequently, it is important for the poor and low-income earners in South Africa to acquaint themselves with all the aforementioned components in order to become financially literate.

It is submitted that some financial consumers, particularly the poor and low-income earners who are informally employed and those who reside in the informal settlements and rural areas in South Africa, are not financially literate. This suggests that the majority of people in South Africa are still financially illiterate and more vulnerable to reckless spending and predatory lending, and they are excluded from enjoying the basic financial services and products that are offered by the formal financial institutions. ${ }^{31}$ Thus, despite the fact that since the demise of apartheid in $1994^{32}$ various legislation and related measures for financial inclusion have been adopted, more still needs to be done to increase financial literacy and curb financial exclusion of the poor and low-income earners in South Africa. ${ }^{33}$ This approach could enhance financial consumer participation in the available financial services and products offered in the formal banking sector to promote financial inclusion in South Africa. ${ }^{34}$ In light of the above, the importance of financial education measures to promote financial literacy and financial inclusion is briefly discussed below.

28 WR Emmons "Consumer-finance myths and other obstacles to financial literacy" (2005) 24 Saint Louis University Public Law Review 335; Zait and Bertea "Financial literacy", above at note 27.

29 Zait and Bertea, ibid.

30 Nanziri and Leibbrandt "Measuring and profiling", above at note 5; L de Koker and N Jentzsch "Financial inclusion and financial integrity: Aligned incentives?" (2011, paper presented at the Shadow Economy, Tax Evasion and Money Laundering Conference, University of Münster, Münster, Germany).

31 See related discussion by KR Pillai, R Carlo and R D'souza "Financial prudence among youth" (2010, Munich Personal RePEc Archive paper 22450).

32 KC Schwartzman and KA Taylor "What caused the collapse of apartheid?" (1999) 27/1 Journal of Political and Military Sociology 109.

33 Chibba "Financial inclusion", above at note 13.

34 TP da Silva, CB dal Magro, MC Gorla and WT Nakamura "Financial education level of high school students and its economic reflections" (2017) 52 Revista de Administração 285. 
Legislative and regulatory measures for financial education in South Africa The Consumer Protection Act (CPA) ${ }^{35}$ was enacted in 2008 to promote a fair and accessible marketplace for consumer products and services in order to develop good norms and national standards for consumer protection in South Africa. The CPA prohibits any unfair marketing and related business practices that are unlawful to financial consumers in South Africa. It also promotes best practices and standards for the dissemination of relevant consumer information in South Africa. ${ }^{36}$ The CPA was probably aimed at encouraging the relevant authorities to promote adequate financial education and financial literacy measures among all financial consumers to enhance financial inclusion in South Africa. The Provincial Consumer Affairs Offices (PCAOs) and/or the Provincial Consumer Protection Offices (PCPOs) were reportedly established under the CPA to increase financial consumer education and related information so as to enhance the financial literacy of financial consumers in all the provinces of South Africa. However, there are still high levels of over-indebtedness among South African people, especially the poor and low-income earners who are financially illiterate. ${ }^{37}$ The CPA does not have specific provisions that oblige the National Consumer Commission (NCC), the PCAOs and the PCPOs to provide financial education to all financial consumers in order to promote financial inclusion of the poor and lowincome earners in South Africa. ${ }^{38}$

The National Credit Act (NCA) ${ }^{39}$ was enacted in 2005 to regulate consumer credit and improve standards of consumer information in South Africa. The NCA prohibits any unfair credit and credit-marketing practices, in order to promote responsible credit granting and prohibit reckless credit lending. ${ }^{40}$ This approach is generally in line with the provision of adequate financial education by the relevant authorities, such as the National Credit Regulator (NCR) and the National Consumer Tribunal (NCT), to increase fair, accessible and efficient credit markets that promote financial literacy and financial inclusion of all financial consumers in South Africa. ${ }^{41}$ The NCA regulates the affairs of financial consumers and credit providers by obliging such credit providers and other financial services providers to provide consumer education on credit and consumer rights, and standardized information on consumer

35 Act 68 of 2008; see preamble and secs 3, 4 and 8-78.

36 See ibid. See further T Woker "Why the need for consumer protection legislation? A look at some of the reasons behind the promulgation of the National Credit Act and the Consumer Protection Act" (2010) 31/2 Obiter 217.

37 Woker, ibid.

38 See CPA, secs 3, 4 and 8-78.

39 Act 34 of 2005; see preamble and secs 3, 4, 60-66 and 72.

40 See ibid. See further Woker "Why the need for consumer protection?", above at note 36. 41 J Isern and L de Koker "AML / CFT: Strengthening financial inclusion and integrity" (2009, CGAP focus note 56); R Singh and R Sankharaj "Financial inclusion: A critical assessment of its concepts and measurement" (2015) 5/1 Asian Journal of Research in Business Economics and Management 12. 
goods and services, in order to protect financial consumers from deception and unfair and/or fraudulent conduct by credit providers and other financial services providers in South Africa. ${ }^{42}$ The NCA requires all credit providers to provide financial consumer education measures to enable all persons to make informed financial decisions and curb over-indebtedness in South Africa. ${ }^{43}$ Nonetheless, the NCA does not expressly provide any measures to enhance the financial inclusion of the poor and low-income earners in South Africa through radical financial education measures. ${ }^{44}$ Moreover, about 50 per cent of the total adult population in South Africa comprises the poor and low-income earners who are financially illiterate. ${ }^{45}$

Additionally, although the NCA has dealt with all credit-related matters and financial education matters since 2006, the NCR has to date struggled to consistently provide financial education workshops, conference presentations, financial education brochures, radio and television interviews to enhance financial consumer literacy and increase financial inclusion in South Africa. ${ }^{46}$ Very few people are aware of the NCR and its functions, particularly in respect of financial inclusion. ${ }^{47}$ Wentzel argues that relatively few low-income earners and the poor have received financial education from the NCR to date. ${ }^{48}$

In 2017, the Financial Sector Conduct Authority (FSCA) was introduced as one of the regulators that promote consumer protection, financial literacy and financial education in South Africa. ${ }^{49}$ Nonetheless, the FSCA has not yet achieved more success in its bid to provide adequate financial education and financial literacy to increase financial inclusion since its inception. ${ }^{50}$

42 NCA, secs 60-100.

43 Ibid.

44 Department of Trade and Industry "Making credit markets work: A policy framework for consumer credit" (2004, Portfolio Committee), available at: <https://www.ncr.org.za/do cuments/pages/background_documents/Credit\%20Law\%20Review.pdf> (last accessed 17 April 2020); A Atkinson and F Messy "Promoting financial inclusion through financial education: OECD / INFE evidence, policies and practice” (2013, OECD Working Papers on Finance, Insurance and Private Pensions 34).

45 Nanziri and Leibbrandt "Measuring and profiling", above at note 5 at 1-11; N Moodley "Improve your financial literacy in 2017" (15 January 2017) Fin24.

46 See NCA, secs 13(a)-(c) and 16(1)(a)-(c), read with sec 12. See further Pearson et al "Balancing responsibilities", above at note 12. S Sibanda and T Sibanda "Financial education in South Africa: Overview of key initiatives and actors" (2016) Innovative Finance for Social Justice 1, argue that the NCR made great efforts to reach financial consumers through various financial education initiatives between 2013 and 2014 in South Africa. Despite this, the NCR has only managed to reach approximately half of the total population of South Africa with its financial education programmes to date.

47 A Wentzel "Financial literacy in South Africa" in C Aprea et al (eds) International Handbook of Financial Literacy (2016, Springer) 329.

48 Ibid.

49 Financial Sector Regulation Act 9 of 2017 (FSRA), secs 57(b) and 58.

50 National Treasury "New twin peaks regulators established" (29 March 2018), available at: <http://www.treasury.gov.za/twinpeaks/Press\%20release\%20Twin\%20Peaks\%20imp1 ementation\%20March2018_FINAL.pdf> (last accessed 17 April 2020) at 1-3; FSCA 
However, it is encouraging to note that the Financial Sector Regulation Act (FSRA) expressly obliges the FSCA to promote financial inclusion for all persons in South Africa. ${ }^{51}$ Despite this, most black people, especially the poor and low-income earners, have remained financially illiterate and they struggle with financial planning. ${ }^{52}$ This follows the fact that the poor and low-income earners have no understanding of most financial services and products. Consequently, most of the poor and low-income earners in South Africa do not have bank accounts. ${ }^{53}$ Thus, although the introduction of the Mzansi account system was a positive step towards promoting financial education, financial literacy and financial inclusion in South Africa, the majority of the poor and low-income earners still do not have access to formal financial services and financial products. ${ }^{54}$ It also appears that the poor and low-income earners do not trust the formal banking sector, since they remain side-lined from it due to their fears of high bank charges and high interests rates. ${ }^{55}$ In light of the above, it is submitted that all the financial services providers, regulatory authorities and other relevant persons should revamp their efforts to curb financial exclusion of the poor and low-income earners through adequate financial consumer education and financial literacy measures. ${ }^{56}$

\section{Over-indebtedness}

Over-indebtedness occurs when a person or financial consumer is unable to timeously satisfy all the accrued debt obligations under any credit agreement and/or facility to which the person or financial consumer is a party. ${ }^{57}$ This

contd

“Celebrating youth month with financial education" (2018), available at: <https://www. fscaconsumered.co.za/Pages/Celebrating-youth-month-with-financial-education.aspx> (last accessed 13 September 2018) (copy on file with the authors).

51 FSRA, sec 58(1)(e). See futher S Mondlana "Role of language in financial inclusion and literacy" (2018) 4 FSB Bulletin 1 at 16; C Rootman and X Antoni "Investigating financial literacy to improve financial behaviour among black consumers" (2015) 8/2 Journal of Economic and Financial Sciences 474; Nanziri and Leibbrandt "Measuring and profiling", above at note 5 .

52 Rootman and Antoni, ibid; RA Ssebagala "Relieving consumer overindebtedness in South Africa: Policy reviews and recommendations" (2017) 28/2 Journal of Financial Counseling and Planning 235; Sibanda and Sibanda "Financial education in South Africa", above at note 46 .

53 JP Wentzel, KS Diatha and VSS Yadavalli "An investigation into factors impacting financial exclusion at the bottom of the pyramid in South Africa" (2016) 33/2 Development Southern Africa 203.

54 Kostov, Arun and Annim "Access to financial services”, above at note 21.

55 Nanziri and Leibbrandt "Measuring and profiling", above at note 5.

56 S Renke "Measures in South African consumer credit legislation aimed at the prevention of reckless lending and over-indebtedness: An overview against the background of recent developments in the European Union" (2011) 74 Journal of Contemporary Roman Dutch Law 208.

57 NCA, sec 79(1). See further S de Wet, I Botha and M Booyens "Measuring the effect of the 
occurs when the affected person incurs too many debts without paying them timeously in accordance with the prior credit agreements. According to the Finscope 2015 report, adult financial inclusion slightly increased from 86 per cent in 2014 to 87 per cent in 2015 while 77 per cent of adults in South Africa had bank accounts with formal banking institutions in 2015. ${ }^{58}$ However, the same report also stipulates that some people in South Africa did not save money. ${ }^{59}$ The majority of the poor and low-income earners are in debt and unable to save their money due to unemployment, lack of surplus income after subsistence deductions and high bank transaction fees. ${ }^{60}$ As a result, the poor and low-income earners who do not save money end up seeking credit loans from other informal sources that charge exorbitant interest rates.

Additionally, most jobless financial consumers end up with many debts that they accumulate in a bid to take care of their day-to-day business. ${ }^{61}$ Ssebagala correctly submits that poverty and financial illiteracy are two of the main causes of over-indebtedness amongst the poor and low-income earners in South Africa. ${ }^{62}$ Moreover, some financial consumers are affected by overindebtedness owing to their low-income jobs which provide them with inadequate finances, while others end up with numerous debts due to poor planning and overspending. ${ }^{63}$ In light of this, financial services providers should consider introducing less onerous requirements for savings accounts in respect of the poor and low-income earners in South Africa, to enable them to save some money and shun overspending and over-indebtedness. This could enhance financial inclusion for the poor and low-income earners in South Africa.

The NCA prohibits reckless borrowing among financial consumers so as to protect them from over-indebtedness. ${ }^{64}$ Furthermore, the NCA prohibits reckless credit granting by financial credit providers and contractual default by financial consumers. ${ }^{65}$ This shows that the NCA seeks to protect the poor and low-income earners in South Africa from the reckless credit granting by

contd

National Credit Act on indebtedness in South Africa" (2015) 8/1 Journal of Economic and Financial Sciences 83.

58 "Finscope South Africa 2015", above at note 4 at 7 and 11.

59 See also S Moyo, D Musona, WT Mbhele and G Coetzee Use and Impact of Savings Services Among Low Income People in South Africa (2002, MicroSave: Market-led Solutions for Financial Services Report).

60 Ssebagala "Relieving consumer overindebtedness", above at note 52.

61 Ibid; RA Ssebagala "What matters more for South African households' debt repayment difficulties?" (2016) 33/6 Development Southern Africa 757.

62 Ssebagala "Relieving consumer overindebtedness", ibid.

63 "Finscope South Africa 2015", above at note 4; M Cohen "72\% of South African income goes to debt" (30 January 2018) Compare Guru, available at: <https://compareguru.co. za/news/debt-south-africans> (last accessed 17 April 2020).

64 NCA, sec 3(c)(i).

65 Id, sec 3(c)(ii). 
financial credit providers that eventually gives rise to their overindebtedness. ${ }^{66}$ For instance, the NCA provides for reckless credit, overindebtedness and debt review measures in a bid to equip financial consumers to avoid over-indebtedness and irresponsible borrowing. ${ }^{67}$ However, poverty, low income and socio-economic hardships have at times caused the poor and low-income earners to accumulate more debts in South Africa without any means to settle them thereafter. ${ }^{68}$ Put differently, high informal credit rates in the form of stokvels and loan sharks that charge excessive interest are commonly utilized in South Africa, to the detriment of the poor and lowincome earners who rely on credit since they do not qualify to have access to most formal financial services and products. ${ }^{69}$ This status quo has been exacerbated by the fact that informal credit platforms (ICPs) are unregulated in South Africa. There are no provisions under the NCA, the CPA and the FSRA that specifically prohibit anyone from relying on ICPs in South Africa. Thus, unlike the formal credit platforms, which are statutorily regulated and/or subject to common law interest rate restrictions such as the in duplum rule,,$^{70}$ the ICPs are not statutorily regulated and are open to abuse by the informal lenders that provide unreasonable high-interest rate loans to the poor and lowincome financial consumers who are normally excluded from accessing the formal financial services and products in South Africa. ${ }^{71}$

\section{High bank fee structure}

Although the financial inclusion rate in South Africa is currently 87 per cent, and the target is to achieve 90 per cent by $2030,{ }^{72}$ the high transaction fees that are charged by banks pose a huge threat to the promotion of financial inclusion of the poor and low-income earners in South Africa. ${ }^{73}$ It is submitted that about 25 per cent of the poor people who do not have bank accounts cite unemployment and high bank fees and transaction charges as the greatest

66 de Wet, Botha and Booyens "Measuring the effect", above at note 57.

67 NCA, secs 3(c) and 79-89. See further Ssebagala "What matters more", above at note 61.

68 Ssebagala, ibid.

69 S Storchi Impact Evaluation of Savings Groups and Stokvels in South Africa: The Economic and Social Value of Group-Based Financial Inclusion (Finmark Trust and SaveAct report, October 2018), available at: <http://finmark.org.za/wp-content/uploads/2018/11/FMT-ImpactEvaluation-of-Savings-Groups-and-Stokvels-in-South-Africa-24-October-2018.pdf> (last accessed 17 April 2020); Kessler et al "Improving financial inclusion", above at note 5.

70 NCA, sec 103(5). Also see M Kelly-Louw "Better consumer protection under the statutory in duplum rule" (2007) 19/3 South African Mercantile Law Journal 337.

71 G Verhoef "Savings and survival in a modern African economy: Informal savings organisations and poor people in South Africa” (2001) 46/2 Historia 519; Wentzel, Diatha and Yadavalli "An investigation", above at note 53.

72 "Finscope South Africa 2015" above at note 4 at 1 and 11.

73 Wentzel, Diatha and Yadavalli "An investigation”, above at note 53; Kessler et al "Improving financial inclusion", above at note 5; L Peyper "High fees tops 6 reasons why South Africans shun banks" (5 May 2017) Fin24; Allen et al "The foundations of financial inclusion", above at note 5 . 
impediment to their opening of formal bank accounts in South Africa. ${ }^{74}$ Additionally, it is submitted that about 40 per cent of banking customers in South Africa often complain about high bank fees and eventually close their bank accounts due to, inter alia, high bank transaction charges. ${ }^{75}$

Kessler et al argue that the banking fees in South Africa are four times higher than those of other banks in countries like Germany, Australia and India. ${ }^{76}$ As a result, the poor and low-income earners are deterred from opening bank accounts in South Africa. Most financial consumers in South Africa complain further that their banked money often loses value through numerous frivolous transaction fees charged by the banks. This status quo has culminated in constant financial exclusion of the poor and low-income earners in South Africa. ${ }^{77}$ Louis and Chartier also argue that the high fee structure that is employed in South Africa is caused by the banking ownership monopoly of four major banks, namely, the Amalgamated Banks of South Africa (ABSA), the Nedbank, the Standard Bank and the First National Bank. ${ }^{78}$ This bank ownership monopoly reduces competition among banks and this eventually discourages financial inclusion, since only a few large banks will monopolize the market in order to share the available financial consumers among themselves without necessarily reducing their transaction fees. Accordingly, the authors submit that competition amongst banking institutions must be encouraged in South Africa to enable many banks to come up with innovative, cheaper financial services and products to offer to financial consumers. This approach could help to reduce high bank fees and the negative perceptions associated with banks in order to promote financial inclusion of the poor and low-income earners in South Africa. ${ }^{79}$ High bank fees are among the main factors that give rise to financial exclusion, especially among the poor and low-income earners who cannot afford and/or qualify to have access to formal banking services and products in South Africa. ${ }^{80}$ High bank fees have driven some financial consumers, particularly the poor and low-income earners, to rely on cash transactions in order to avoid high bank transaction costs. ${ }^{81}$ The trend of withdrawing income immediately after receipt and/or

74 A Demirgüç-Kunt and L Klapper "Measuring financial inclusion: The global findex database" (2012, World Bank Policy Research working paper 6025) at 3.

75 Kessler et al "Improving financial inclusion", above at note 5 at 8.

76 Ibid. See also Ikdal "6 Challenges to financial inclusion", above at note 14.

77 Kessler et al, id at 8.

78 Louis and Chartier "Financial inclusion in South Africa", above at note 5 at 182-84.

79 Id at 182-96.

80 SA Ouma, TM Odongo and M Were "Mobile financial services and financial inclusion: Is it a boon for savings mobilization?" (2017) 7/1 Review of Development Finance 29.

81 Research Report on Mobile Money in South Africa (September 2017, Finmark Trust), available at: <http://www.finmark.org.za/wp-content/uploads/2017/12/Final-Report-on-MobileMoney-in-South-Africa-v11.1_clean_digital_CB.pdf> (last accessed 21 July 2019) at 24; Kessler et al "Improving financial inclusion", above at note 5 . 
utilizing bank accounts as mailboxes and for their remittances ${ }^{82}$ increases financial exclusion for the poor and low-income earners in South Africa.

\section{Mistrust of the formal banking sector and the fear of fraud}

High levels of financial illiteracy amongst the poor and low-income earners ${ }^{83}$ have contributed to their mistrust of the banks and other formal financial services providers in South Africa. ${ }^{84}$ Various factors, such as high bank fees, high interest rates, misleading advertisements and poor marketing of financial products, have led the poor and low-income earners to be skeptical about the banks' financial products and financial services. Ouma, Odongo and Were argue that some banking institutions ambush financial consumers into purchasing insurance and financial products without providing prior adequate financial educational awareness measures on such products. ${ }^{85}$ The authors submit that the aforesaid ambush practice includes, inter alia, the selling of funeral policies and other non-essential insurance financial products to the poor and low-income earners. This exacerbates poverty and financial exclusion of the poor and low-income earners in South Africa. ${ }^{86}$ Given this background, it is submitted that South African financial institutions must carefully provide adequate financial education before they offer any financial products and financial services to their clients, in order to promote financial inclusion and avoid over-burdening the poor and low-income earners with unnecessary products. This view is further supported by Adam Ikdal, who argues that some banking institutions deliberately offer non-essential funeral coverage and micro-loans to the poor and low-income earners, which culminates in their overindebtedness. ${ }^{87}$ These and other illicit practices of financial services providers have to date increased the mistrust of banking and financial institutions by the poor and low-income earners in South Africa. Furthermore, the recent mismanagement and embezzlement of over R2 billion funds of the poor, pensioners and low-income earners at the Venda Building Society mutual bank (VBS bank) could have contributed to the

82 C Coovadia Annual Report: Making Financial Markets Work for the Poor (2017, Finmark Trust).

83 Nanziri and Leibbrandt "Measuring and profiling", above at note 5 at 1-11; Mondlana "Role of language", above at note 51 at 16.

84 A Demirgüç-Kunt and L Klapper "Measuring financial inclusion: Explaining variation in use of financial services across and within countries" (2013) Brookings Papers on Economic Activity 279; Ikdal "6 Challenges to financial inclusion", above at note 14 at 1-5; DK Maduku "The effect of institutional trust on internet banking acceptance: Perspectives of South African banking retail customers" (2016) 19/4 South African Journal of Economic and Management Sciences 533; JM Chigada and B Hirschfelder "Mobile banking in South Africa: A review and directions for future research" (2017) 19/1 South African Journal of Information Management 1.

85 Ouma, Odongo and Were "Mobile financial services", above at note 80 at 30-34.

86 Ikdal "6 Challenges to financial inclusion", above at note 14 at 2; Ouma, Odongo and Were, ibid.

87 Ikdal, id at $1-5$. 
ongoing mistrust of banks by some financial consumers in South Africa. ${ }^{88}$ The VBS scandal indicates that mutual banks are poorly regulated in South Africa. This has further increased the mistrust of the entire banking sector by the poor and low-income earners in South Africa. ${ }^{89}$

Most of the poor and low-income earners do not utilize online banking and mobile banking due to fears of internet-related fraudulent activities that could be perpetrated through banks in South Africa. ${ }^{90}$ Additionally, some poor and low-income earners prefer transacting in cash due to their strong belief that it is cheaper than online banking and mobile banking. ${ }^{91}$ It is submitted that reliance on cash increases impulsive buying, which is detrimental to the financial inclusion of the poor and low-income earners in South Africa. The National Stokvel Association of South Africa submits that 40 per cent of the poor and low-income earners in South Africa prefer trust-based models such as stokvels, which are community-based, to avoid default payments and high bank charges. ${ }^{92}$ A stokvel allows its consumers to create a pool of savings where members agree to contribute a certain amount of money that is distributed fairly amongst them after a certain period of time. This stokvel model is convenient for some poor and low-income earners and serves as a great tool that encourages them to save their money. ${ }^{93}$ Furthermore, the poor and lowincome earners who prefer stokvels cite their use of simple common language as one of the leading factors in choosing them, while they are forced to shun formal banking services and financial products that are normally offered in difficult technical language. ${ }^{94}$ A stokvel allows community members to use their own common language, which is less complex, and no bank interest rates are required. As a result, stokvels are much preferred by the poor and low-income earners in South Africa than the formal banks. ${ }^{95}$

\section{Lack of documentation and high number of informal businesses}

The excessive documentation that is strictly required by banks to open bank accounts and/or access other financial products has resulted in the financial

88 C Kgosana and M Afrika "The great VBS bank heist" (24 June 2018) Business Day; S Masondo and D Van Rensburg "How VBS was plundered" (24 June 2018) City Press.

89 Ikdal "6 Challenges to financial inclusion", above at note 14 at 1-5; Kessler et al "Improving financial inclusion" above at note 5.

90 Ikdal, id at 3.

91 Id at 1.

92 Id at 4; Kessler et al "Improving financial inclusion", above at note 5; Storchi "Impact evaluation", above at note 69 at 84-100.

93 S Matuku and E Kaseke "The role of stokvels in improving people's lives: The case in Orange Farm, Johannesburg, South Africa” (2014) 50/4 Social Work 504; Verhoef "Savings and survival", above at note 71 at 523-42.

94 Verhoef, ibid.

95 Ibid; H Bester et al Implementing FATF Standards in Developing Countries and Financial Inclusion: Findings and Guidelines (May 2008, Genesis Analytics final report, version 5.2, Johannesburg, South Africa). 
exclusion of those financial consumers who do not have such documentation, especially the poor and low-income earners in South Africa. ${ }^{96}$ For instance, banks usually require such documentation in order for them to comply with the "know your customer" (KIC) requirements, ${ }^{97}$ meet customer due diligence measures, and keep records of all their clients. ${ }^{98}$ Moreover, banks require several documents from potential financial customers, such as valid identity documents, bank statements, proof of income, proof of residence and a minimal balance prior to the opening of accounts, which most poor and low-income earners do not have. ${ }^{99}$ In addition, the approval of new bank accounts often takes a long time, and this further discourages the poor and low-income earners from accessing such financial services and products. This follows the fact that most poor and low-income earners often require immediate cash for their day-to-day dealings, yet most banking and related institutions have too onerous requirements for the granting of short and long term loans. ${ }^{100}$ Consequently, the poor and low-income earners in South Africa are forced to rely on informal financial services providers and the high interest informal credit systems of loan sharks (mashonisas) that are relatively quick and less onerous. ${ }^{101}$

The authors concur with de Koker, who argues that the more that people use the informal banking sector, the more challenging it is for regulatory authorities to effectively implement anti-money laundering measures to combat the financing of terrorism in their respective countries. ${ }^{102}$ This follows the fact that the onerous bank processes and strict documentation requirements push criminals out of the formal banking sector into the informal sector. Accordingly, regulatory authorities face a huge challenge when investigating and/or prosecuting offenders who rely on illegal informal banking systems to commit money laundering and other illicit activities. ${ }^{103}$ It is very difficult to keep track of illegal activities that are perpetrated by offenders in the informal sector, and eventually, the integrity of the financial markets and the banking sector will eventually be negatively affected. The status quo is worsened by the fact that South Africa has high levels of informal businesses, owing to high levels of unemployment. ${ }^{104}$ For instance, Statistics South Africa indicated that more than 1.5 million people in

96 Ikdal "6 Challenges to financial inclusion", above at note 14.

97 See Financial Intelligence Centre Act 38 of 2001 as amended (FICA), sec 21; see further D Karlan, AL Ratan and J Zinman "Savings by and for the poor: A research review and agenda" (2014) 60/1 Review of Income and Wealth 36.

98 See FICA, secs 22 and 22A.

99 Ikdal "6 Challenges to financial inclusion", above at note 14.

100 Ibid.

101 L de Koker "Money laundering control and suppression of financing of terrorism: Some thoughts on the impact of customer due diligence measures on financial exclusion" (2006) 13/1 Journal of Financial Crime 26; Ikdal, ibid.

102 de Koker, ibid.

103 Ibid.

104 Ikdal "6 Challenges to financial inclusion", above at note 14. 
South Africa had small informal businesses in 2013. Most of these people who conduct unregistered businesses are unable to open basic bank accounts because of the numerous stringent bank requirements. ${ }^{105}$ In this regard, it is submitted that the banks and other financial services providers should consider relaxing their rules and requirements for opening bank accounts, to promote financial inclusion of the poor and low-income earners in South Africa. There must be a fine balance between maintaining the measures to prevent money laundering and the financing of terrorist activities, and the promotion of financial inclusion for the poor and low-income earners.

\section{Lack of a specific and adequate statutory regulatory framework for financial inclusion}

There is no specific statute that regulates and promotes financial inclusion for the poor and low-income earners in South Africa. Put differently, the NCA, the $\mathrm{CPA}$, the FICA (Financial Intelligence Centre Act) and the FSRA do not specifically provide for the promotion of financial inclusion for the poor and lowincome earners in South Africa. This haphazard approach could have increased the financial exclusion of the poor and low-income earners in South Africa. Owing to this confusion, most of the poor and low-income earners have resorted to informal financial services providers, to their detriment and financial exclusion. Nonetheless, it is encouraging to note that the FSRA has, inter alia, introduced the Prudential Authority (PA) ${ }^{106}$ and the FSCA $^{107}$ to regulate and supervise financial product providers and financial services providers so as to protect South Africa's financial customers, financial institutions and financial markets. For instance, both the $\mathrm{PA}^{108}$ and the $\mathrm{FSCA}^{109}$ are obliged to adopt relevant measures to promote financial inclusion in South Africa. The FSCA is further obliged to promote fair treatment of financial customers by financial institutions in South Africa. It is also required to provide financial consumers with financial education programs to promote financial literacy and financial inclusion in South Africa. ${ }^{110}$ While these developments and efforts are commendable, there are no provisions in the FSRA that specifically promote financial inclusion of the poor and low-income earners in South Africa. Moreover, the FSRA does not clearly stipulate how the FSCA may promote financial inclusion for the poor and low-income earners in South Africa.

\section{Uneven bank concentration}

The South African banking sector has grown since 1994, and a number of banks and financial products have been introduced there to date. For instance,

105 See FICA, secs 21, 22, 22A, 23 and 24.

106 FSRA, secs $32-55$.

$107 \mathrm{Id}$, secs $56-72$.

$108 \mathrm{Id}$, sec 34(1)(e).

$109 \mathrm{Id}$, sec 58(1)(e).

110 Id, sec 57(b). 
the distribution of automated teller machines (ATMs) has increased to a network of over 5,000 branches and nearly 30,000 ATMs have been installed in South Africa. ${ }^{111}$ Despite this, most financial services providers and banking institutions are still concentrated in urban areas. Consequently, financial consumers in rural areas and other informal sectors struggle to access such financial services and products in their communities. Thus, despite the advent of mobile money, instant cash and other measures that were adopted to enhance financial inclusion, most people in rural areas and informal sectors are still largely excluded from accessing basic financial services and financial products in South Africa. Accordingly, it is submitted that there is an uneven balance and concentration of banks and other financial institutions in South Africa. ${ }^{112}$ The aforesaid imbalance has indirectly increased the financial exclusion of the poor and low-income earners in South Africa. ${ }^{113}$

\section{RECOMMENDATIONS}

South African banks should be properly regulated to ensure that they do not charge exorbitant bank fees. Thus, the current South African statutory regulatory enforcement framework for banks and financial products must be revamped in light of the plight of the poor and low-income earners, in order to carefully relax the requirements for opening bank accounts and/or accessing other basic financial services and products. This could encourage the poor and low-income earners to trust the formal banking sector in South Africa. The banks and other related financial institutions should carefully relax their requirements regarding relevant documentation for the poor and low-income earners without necessarily exposing other financial customers to risks such as fraud, financial terrorism and money laundering. Banks and other financial institutions should be encouraged to establish branches in rural and informal settlements to curb the current uneven bank concentration in the main South African towns and cities. The government, banks and other financial institutions should further develop and establish financial education and financial literacy programmes in rural and informal settlements to promote financial inclusion for the poor and low-income earners in South Africa. Lastly, it is submitted that policy makers should seriously consider enacting a specific and adequate statute for financial inclusion to combat the financial exclusion of the poor and low-income earners in South Africa.

\section{CONCLUSION}

As indicated in this article, South Africa has made commendable progress towards the promotion of financial inclusion in South Africa since 1994 to

111 Louis and Chartier "Financial inclusion in South Africa", above at note 5 at 179

112 Id at 179-80 and 194.

113 Id at 180-96. 
date. For instance, the adoption of the NDP national goal to attain 90 per cent financial inclusion in South Africa by 2030 should be welcomed as a positive commitment on the part of the government to increase financial inclusion. ${ }^{114}$ Furthermore, the recent enactment of the FSRA, which obliges the PA and the FSCA to promote financial inclusion, is another positive step. Nevertheless, unemployment, poverty, financial illiteracy, over-indebtedness, high bank fees, mistrust of the banking system, lack of relevant national identity documentation, and a poor legislative framework for financial inclusion have remained the main challenges to the full realization of financial inclusion in South Africa to date. Consequently, it is submitted that the government and other relevant stakeholders should consider adopting appropriate measures to combat poverty and unemployment in South Africa. This approach could promote financial inclusion of the poor and low-income earners in South Africa. Put differently, if the poor and low-income earners are empowered with well-paid jobs, they may end up using their salaries to open bank accounts and access other formal financial services. It is also submitted that the FSCA, the NCT, the NCC and the NCR should regularly conduct financial literacy and educational awareness programmes that are mainly aimed at promoting financial inclusion for the poor and low-income earners in all the rural areas and informal settlements of South Africa. This could equip and encourage financial consumers, especially the poor and low-income earners, to make well-informed financial decisions and curb over-indebtedness and financial exclusion. ${ }^{115}$ Moreover, South African policy makers should consider revamping the banking regulation in order to curb high bank fees, reduce mistrust of the banking sector and prevent the recurrence of the mismanagement of banks as highlighted by the VBS scandal. Policy makers should further consider enacting a separate and specific statute to regulate financial inclusion with adequate provisions that discourage financial exclusion of the poor and low-income earners in South Africa. Lastly, the banks and related financial services providers should establish more branches in rural areas and informal settlements to encourage financial inclusion of the poor and lowincome earners in South Africa

\section{CONFLICTS OF INTEREST}

None

114 National Planning Commission "National development plan 2030", above at note 25 at 150-51.

115 L Klapper and D Singer "The role of demand-side data: Measuring financial inclusion from the perspective of users of financial services" (paper presented at the CEMLAIFC Satellite Seminar at the ISI World Statistics Congress on Financial Inclusion, Marrakech, Morocco, 14 July 2017); M Maziya and T Zwane "Financial inclusion is more than just access to credit” (3 November 2017) Mail \& Guardian. 